\title{
Exposure of healthcare workers in England, Wales, and Northern Ireland to bloodborne viruses between July 1997 and June 2000: analysis of surveillance data
}

Barry Evans, Winnie Duggan, Juliet Baker, Mary Ramsay, and Dominique Abiteboul on behalf of the Occupational Exposure Surveillance Advisory Group

The transmission of bloodborne viruses to healthcare workers can have serious consequences not only for clinical practice but also, because of the requirements of health and safety legislation, for their employers. ${ }^{1}$ In spite of guidance and education, ${ }^{2}$ however, many healthcare workers continue to be exposed to bloodborne viruses from percutaneous, mucocutaneous, or other injuries. An enhanced system of surveillance of occupational exposure to bloodborne viruses was introduced in mid-1997, developing the passive system that was set up after the first reported case (in 1984) in the United Kingdom of HIV seroconversion associated with needlestick injury. ${ }^{3}$

\section{Methods and results}

Since July 1997 occupational health departments have been requested to complete a brief form outlining the circumstances of any work related exposure to potentially infectious material from patients who are known to be positive for HIV antibodies or hepatitis $\mathrm{C}$ antibodies, or for hepatitis B surface antigens. For exposures to HIV or hepatitis C virus, the follow up at six weeks includes more information about the incident, baseline testing of both the healthcare worker and the source patient, and, for exposure to HIV, details of post-exposure prophylaxis.

A total of 813 initial reports were received of exposure of healthcare workers to bloodborne viruses between July 1997 and June 2000: 725 reports of exposure to only one of the bloodborne viruses, 83 to two, and five to all three. After records with missing information were excluded, the most commonly reported exposed groups were nurses and midwives
(45\% (308/678) of the health professionals exposed) and doctors (38\% (255/678)) (table), and percutaneous injuries were the most commonly reported type of exposure $(70 \%)$.

Six week follow up reports were received for 507 of the incidents. These recorded that $64 \%$ (323) involved exposure during a procedure, $20 \%$ (100) after the procedure but before disposal of equipment, and 13\% (64) during or after disposal; in $4 \%$ (20) the nature of the incident was not reported. Post-exposure prophylaxis was recorded for 138 of the healthcare workers exposed to HIV: 43 were known to have fully completed four weeks of treatment, 19 workers completed the course for some drugs, and 38 completed none. In 38 workers post-exposure prophylaxis was started but the length of treatment was not recorded. Side effects caused by post-exposure prophylaxis were recorded in 77 healthcare workers.

One transmission occurred among 293 exposures to HIV despite post-exposure prophylaxis, and none in 462 exposures to hepatitis $\mathrm{C}$ virus. However, reports of follow up at six months have not been received for all of these.

\section{Comment}

Thanks to the cooperation of occupational health departments, the enhanced surveillance system has been successful both in increasing the number of incidents reported and in expanding its coverage to hepatitis B and C. The case of HIV transmission described above brings the total number of occupationally acquired HIV infections reported in the United Kingdom to five. A further 11 reported cases among
Communicable Disease

Surveillance Centre, Colindale, London NW9 5EQ

Barry Evans consultant epidemiologist Winnie Duggan research nurse Juliet Baker research nurse Mary Ramsay consultant

epidemiologist Study Group on Occupational Blood Exposure, Faculté Bichat, Paris Cedex

18 , France

Dominique

Abiteboul

occupational

physician

Correspondence to: B Evans

bevans@phls.org.uk

BMJ 2001;322:397-8

Number of reports of exposure to bloodborne viruses among healthcare workers

\begin{tabular}{|c|c|c|c|c|c|c|c|}
\hline \multirow[b]{2}{*}{ Occupation } & \multicolumn{4}{|c|}{ Nature of exposure } & \multicolumn{3}{|c|}{ Viruses* } \\
\hline & $\begin{array}{l}\text { Percutaneous } \\
(\mathrm{n}=568)\end{array}$ & $\begin{array}{l}\text { Mucocutaneous } \\
(\mathrm{n}=186)\end{array}$ & $\begin{array}{l}\text { Bites, scratches, and } \\
\text { unknown }(n=59)\end{array}$ & $\begin{array}{c}\text { No of } \\
\text { incidents }\end{array}$ & $\begin{array}{c}\text { HIV } \\
(\mathrm{n}=293)\end{array}$ & $\begin{array}{c}\text { Hepatitis C } \\
(n=462)\end{array}$ & $\begin{array}{c}\text { Hepatitis B } \\
(n=151)\end{array}$ \\
\hline Nurses and midwives & 210 & 82 & 16 & 308 & 108 & 184 & 49 \\
\hline Doctors & 200 & 41 & 14 & 255 & 104 & 150 & 37 \\
\hline Healthcare assistants & 20 & 5 & 4 & 29 & 7 & 19 & 4 \\
\hline Laboratory workers & 9 & 5 & 0 & 14 & 8 & 4 & 2 \\
\hline Dentists & 11 & 0 & 0 & 11 & 3 & 6 & 4 \\
\hline Phlebotomists & 8 & 1 & 0 & 9 & 2 & 7 & 1 \\
\hline $\begin{array}{l}\text { Dental hygienists and } \\
\text { nurses }\end{array}$ & 5 & 0 & 3 & 8 & 6 & 2 & \\
\hline Paramedics & 2 & 3 & 1 & 6 & 1 & 5 & 1 \\
\hline Radiographers & 2 & 3 & 1 & 6 & 3 & 3 & \\
\hline $\begin{array}{l}\text { Operating department and } \\
\text { theatre assistants }\end{array}$ & 4 & 1 & 0 & 5 & 1 & 3 & 1 \\
\hline Technicians & 5 & 0 & 0 & 5 & 1 & 3 & 1 \\
\hline Porters & 1 & 3 & 1 & 5 & 3 & 3 & 1 \\
\hline Others & 6 & 7 & 4 & 17 & 9 & 8 & 6 \\
\hline Not known & 85 & 35 & 15 & 135 & 37 & 65 & 44 \\
\hline
\end{tabular}

*Includes patients who were dually or triply exposed. 
healthcare workers in the United Kingdom are associated with work overseas in areas of high prevalence of HIV. The low rate of completion of the recommended course of post-exposure prophylaxis indicates the importance of regular support during the four weeks of the course.

In March 2000 a six month follow up form was introduced that asks retrospectively for evidence of the healthcare worker's post-exposure infection status. Although transmissions of HIV among healthcare workers after recorded exposures are unlikely to go unrecognised, assessing transmission rates of hepatitis $\mathrm{C}$ virus requires routine testing. No seroconversions have occurred among the 142 healthcare workers for whom post-exposure testing for hepatitis $\mathrm{C}$ virus has been formally reported $(95 \%$ confidence interval $0 \%$ to $3.35 \%)$, indicating a lower risk of transmission of this virus than has been reported elsewhere. ${ }^{45}$ However, only 102 exposures were due to percutaneous needlestick injury, and only 65 of these were from a hollow bore needle. Such exposures probably do carry a considerable risk of transmission of hepatitis $\mathrm{C}$ virus. One report of such a transmission was received, but the exposure occurred in 1996, before the enhanced surveillance period.

Although exposures to hepatitis B virus among vaccinated individuals may not be well reported, the 151 occupational exposures recorded here indicate the continuing importance of maintaining rigorous programmes of vaccination of healthcare workers.
The Occupational Exposure Surveillance Advisory Group, which gave helpful comments, comprised: Mark Bale and David Mullooly (Health and Safety Executive); Janet Carruthers, Paul Grime, and Lynne Risi (occupational health department, King's College Hospital); Eric Monteiro (genitourinary medicine clinic, Leeds General Infirmary); Susan Turnbull (Department of Health); Sian Williams (occupational health department, Royal Free Hospital); David Goldberg and Fiona Raeside (Scottish Centre for Infection and Environmental Health); Howard Vaile, Caroline Ireland, and Stella Sawyer (occupational health department, Chelsea and Westminster Hospital); Carole Fry (Department of Health); and Jane Watts (occupational health department, Charing Cross Hospital). We thank Janet Mortimer of the Communicable Disease Surveillance Centre for providing constructive comments on drafting, and Pauline Rogers for statistical advice

Funding: JB and then WD were supported by a grant from the Health and Safety Executive.

Competing interests: None declared.

1 UK Health Departments. Hepatitis B infected health care workers: guidance on implementation of Health Service Circular 2000/020. London: Department of Health, 2000.

2 UK Health Departments. Guidance for clinical health care workers: protection against infection with bloodborne viruses. London: Department of Health, 1998.

3 Needlestick transmission of HTLV-III from a patient infected in Africa [editorial]. Lancet 1984;ii:1376-7.

4 Cardo DM, Bell DM. Bloodborne pathogen transmission in health care workers: risks and prevention strategies. Infect Dis Clin North Am 1997;11:331-46.

5 Dore GJ, Kaldor JM, McCaughan GW. Systematic review of role of polymerase chain reaction in defining infectiousness among people infected with hepatitis C virus. BMJ 1997;315:333-7.

(Accepted 20 October 2000)

\title{
Issues in the management of prisoners infected with HIV-1: the King's College Hospital HIV prison service retrospective cohort study
}

\author{
Simon Edwards, Melinda Tenant-Flowers, Joseph Buggy, Peter Horne, Nick Hulme, \\ Philippa Easterbrook, Chris Taylor
}

Correspondence to: Simon Edwards SEdwards@cichs-tr. nthames.nhs.uk

continued over

BMJ 2001;322:398-9

\section{bmj.com}

This article is part of the BMJ's randomised controlled trial of open peer review. Documentation relating to the editorial decision making process is available on the BMJ's website
Concern has been raised about the quality of health care provided to prisoners in England and Wales. ${ }^{12}$ The management of prisoners infected with HIV-1 is challenging: a high proportion are injecting drug users, there are issues regarding confidentiality, and administering complex antiretroviral regimens may be difficult in prison. We reviewed our experience of providing specialist HIV care to prisoners between October 1994 and July 1999.

\section{Participants, methods, and results}

In October 1994, King's College Hospital was contracted to provide care to male prisoners with HIV-1 and sexually transmitted diseases at Wandsworth and Brixton prisons in south London. Prisoners access the service through self referral or referral by wing officers and prison healthcare workers.

Between October 1994 and July 1999 six prisoners were newly diagnosed as positive for antibodies to HIV-1 and 121 said that they had previously tested positive for antibodies to HIV-1. Of those 121, 75 were confirmed as positive for antibodies to HIV-1 and 25 tested negative for antibodies to HIV-1. Fourteen of the remaining 21 who declined to be tested gave information to support their claim, including their HIV treatment centre. In all cases this information proved to be false. Documented reasons for this subterfuge included the desire for a letter pleading mitigating circumstances in court or a request for food supplements, sedatives, or opioids.

Of 81 patients confirmed as positive for antibodies to HIV-1, $77 \%(62 / 81)$ were white and $16 \%(13 / 81)$ were black-African. The median age at first assessment in prison was 33 (range 23-65) years and the main HIV risk factor recorded was injecting drug use $(59 \%$; $48 / 81$ ). The median CD4 count was $210 \times 10^{6} / 1$ (range $\left.4-740 \times 10^{6} / 1\right)$ and a fifth were severely immunosuppressed $\left(\mathrm{CD} 4<50 \times 10^{6} / 1\right)$. Twenty one $(26 \%)$ had AIDS, 41 (51\%) were coinfected with hepatitis C, and five $(6 \%)$ also had chronic hepatitis $\mathrm{B}$.

Inmates were reviewed regularly to assess clinical status and adherence to antiretroviral treatment. As expected, they were significantly more likely to keep 